\title{
ORGANIZATIONAL CULTURE AS A PREDICTOR OF JOB SATISFACTION: THE ROLE OF AGE AND GENDER
}

\author{
Pooja Sharma* \\ Received: 28. 7. 2016 \\ Accepted: 9. 6.2017 \\ Preliminary communication \\ UDC 005.73:658.3-053/-055>(540) \\ This paper studies the impact of organizational culture on job satisfaction of the \\ employees taking into account their gender and age. The current study was \\ conducted in three Information Technology companies in the city of Pune, state of \\ Maharashtra (India), with an effective sample of 220 IT professionals. The \\ responses from employees were collected using organizational cultural profile and \\ job descriptive index. Data was analysed using descriptive analyses, stepwise \\ regression and t- test. The findings reveal that organizational cultural values such \\ as fairness, growth opportunities and reputation of organization have a positive \\ effect on the job satisfaction, whereas organizational traits like aggressiveness \\ have a negative influence on job satisfaction. Further analysis revealed that there \\ is a gender difference in the perception of organizational values.
}

Keywords: Organizational culture, Job satisfaction, Age, Gender, India

\section{INTRODUCTION}

Job satisfaction is among the most studied concepts in organizational studies. Job satisfaction is a multi- dimensional construct with a variety of definitions and related concepts which have been studied since the beginning of the 20th century. Smith (1969) suggested that job satisfaction can be categorized on the basis of individual's needs. Job satisfaction is defined as the sum total of individual's stance towards various job-related factors including work itself, supervisors, colleagues, working conditions, compensation and reward and recognition (Schultz et. al., 2003). Individuals are more satisfied when they feel that their abilities, values and experiences are adequately used in the organization (Buitendach and De Witte, 2005). Organizational culture has

* Pooja Sharma, Assistant Professor, SCMHRD, Symbiosis International University, Pune, Maharashtra, India, E-mail: poojasharma@scmhrd.edu 
Management, Vol. 22, 2017, 1, pp. 35-48

P. Sharma: Organizational culture as a predictor of job satisfaction: The role of age and gender

become a widely researched topic in the last few years. Uttal $(1983$, p. 66) has defined organization culture as "a system of shared values (what is important) and beliefs (how things work) that interact with an organization's people, organizational structures and control systems to produce behavioural norms". Shein (1985, p. 6) explained organizational culture as "deeper level of basic assumptions and beliefs that are shared by members of an organization, that operate unconsciously and that define in a basic taken-for-granted fashion the organization's view of itself and its environment".

The primary reason for which job satisfaction has become such a heavily studied notion is its impact on various organizational outcomes such as commitment, performance and identification. Researchers have studied job satisfaction broadly in the context of an organization and on individual level, but the latter has received greater attention (Judge et al., 2002). Huang and $\mathrm{Wu}$ (2000), Odom et al. (1990) and Silverthorne (2004) have studied the impact of different types and dimensions of organizational culture on job satisfaction, but studies pertaining to organizational values and job satisfaction are rare. Thus, the current study attempts to explore the effects of various organizational values on job satisfaction. Organizational values, along with attitudes and norms, compose organizational culture (Schein, 1985). Employee's own personality, preferences and characteristics have a great impact on how they perceive organizational culture (Palthe and Kossek, 2003). Researches have also linked age, gender, job tenure and education to the job satisfaction of the employees (Moyes et al., 2006; Igbaria and Guimaraes, 1993). Therefore, the present study also investigates the influence of age and gender on the relationship between organizational culture and job satisfaction.

\section{LITERATURE REVIEW}

\subsection{Job satisfaction, organizational culture and their relationship}

Researchers have always been interested in knowing the factors that influence the attitudes and the behaviour of the employees. Aiken et al. (2000) revealed working condition to affect the employee's attitude. Similarly, Verplanken (2004) suggested individual's values to be an important aspect shaping their perception towards organization. Therefore, organizational researchers have been interested in understanding the various organizational values that influence various job attitudes. Odam et al. (1990), in their study of organizational culture, job satisfaction and organizational commitment revealed that the individual's job satisfaction and organizational commitment is negatively affected by bureaucratic culture. Silverthorne (2004) concluded in 
Management, Vol. 22, 2017, 1, pp. 35-48

P. Sharma: Organizational culture as a predictor of job satisfaction: The role of age and gender

his study that job satisfaction of the employees is impacted by the supportive organizational culture, innovative organizational culture and bureaucratic organizational culture, in descending order.

There has been a lack of consensus amongst researchers regarding the influence of cultural dimensions on job satisfaction. Huang and $\mathrm{Wu}(2000)$ found job satisfaction of the employees to be positively influenced by control \& management, result orientation and professionalism. Platonova et al. (2006) revealed that the organizations where employees feel their performance is recognized have high job satisfaction. However, McKinnon et al. (2003) found stability, respect for people and aggressiveness to have a positive effect on job satisfaction of the employees. Therefore, there is still a need to investigate the relationship between organizational culture and job satisfaction (Detert et al., 2000).

Organizational culture profile $(O C P)$ is widely used to measure the organizational culture (Sarros et al., 2005), but there are very few studies that have investigated the impact of distinct cultural values on job satisfaction (Bellou, 2007). Therefore, the main goal of this study is to examine the influence of organizational values on job satisfaction and this goal is made evident in the first hypothesis of the research: H1: Job satisfaction of the employees will be influenced by few organizational
culture values.

\subsection{The role of gender and age}

Various organizational researchers have studied the impact of demographic characteristics on individual and organizational outcomes. There is ample research studying the effect of age and gender on individual's job satisfaction and organizational culture. Researchers, such as Bartol and Wortman (1975), Clark and Oswald (1996), have found female employees to be more satisfied than male employees, whereas Brief et al. (1977) and Coh and Koh (1991) found male employees to be more satisfied than their female counterparts. A number of researchers studied the effect of different job satisfaction facets on gender. Results revealed that males draw more satisfaction from factors such as salary, promotion and attitude of one's supervisor whereas job satisfaction of female employees was found to be more affected by co-workers and working conditions (Okpara et al., 2005; Okpara, 2006). However vast the existing research is, studies demonstrating the effect of age on job satisfaction of employees have shown mixed results. Researchers such as Ang et al. (1993), 
Decker and Borgen (1993), Savery (1996), Weisma et al. (1981), have found that the job satisfaction of the individuals increase with age, whereas Pook et al. (2003) and Sarker et al. (2003) have found no such relationship between job satisfaction and age in their studies.

Researchers, such as Aaltio and Mills (2002), Acker (1998), Britton (2000), have found gender to be an important element of organizational culture. Ely and Meyerson (2000), in their study of gender theories revealed that male and female employees follow different socialization processes which set them increasingly apart from each other and more homogeneous amongst themselves. There are very few studies that have studied the perceptual difference between gender and age on organizational culture values.

One such study, by Wagner et al., (2001), revealed that male and female employees perceive differently some key organizational culture values such as organizational pride, performance, communication, development and openness. Wager et al. (1984) revealed that employees belonging to similar age groups tend to have better communication since they usually share certain common values. Similarly, Helm and Stern (2001) found that employees perceive organizational culture values such as organizational pride, teamwork, relationship with co-workers, openness and leadership differently, depending on their age. In the current study, employees were divided into two groups on the basis of their mean age. Such division is logical given the fact that the age of the employees ranged from 22 to 50 years, whereby 35 years of age appears to be close to the middle of their IT careers.

Based on the previous research in this area, the present study aims to test two more hypotheses:

H2: The effect of organizational culture on job satisfaction will be influenced by employees' gender.

H3: The effect of organizational culture on job satisfaction will be influenced by employees' age.

\section{METHODOLOGY}

\subsection{Sample and procedure}

The current study was conducted in three multinational companies, located in the city of Pune, state of Maharastra (India). The questionnaires were e- 
Management, Vol. 22, 2017, 1, pp. 35-48

P. Sharma: Organizational culture as a predictor of job satisfaction: The role of age and gender

mailed to respondents using their personal e-mail addresses. Total of 300 questionnaires were distributed, 250 questionnaires were returned out of which 30 were incomplete and they were not included in the research. The effective sample used in the study was of 220 employees from three multinational IT companies, yielding the effective response rate of $73 \%$.

Both male and female employees were adequately represented in the sample. Out of the total, $99(45 \%)$ were female respondents with the mean age of 33 and $121(55 \%)$ were males with the mean age of 37 . Using the mean age as a threshold revealed quite a balanced sample in terms of gender proportion. As for job positions, $40 \%$ were software consultants, $35 \%$ were senior software consultant and $25 \%$ were team leaders. The mean tenure in the organization was 10 years and average work experience was 14 years. Moreover, $60 \%$ possessed a post graduate degree while $40 \%$ possessed a graduate degree.

\subsection{Measures}

The questionnaire was divided into two sections, first part consisted of demographic information and second part consisted of organizational culture and job satisfaction questionnaire. In the first part, questions pertaining to employee's gender and age were asked. On the basis of mean age (35 years), groups were formed as older (over 35 years of age) and younger employees (below 35 years of age).

Organizational culture was studied using O'Reilly et al., (1991) Organizational Culture Profile questionnaire. OCP consists of 54 value statements such as "autonomy", "fairness", "risk taking" that are used to measure organizational value profile and individual preferences. In the current study, participants were asked to score organizational value profiles based on the extent to which they were prevalent in the organization. Participants were asked to score the value profile on a 5-point Likert scale ranging from 1 (strongly disagree) to 5 (strongly agree). The reliability of OCP was measured using Cronbach's alpha, which equals 0.80 .

Job satisfaction was measured using the shortened version of JDI (Smith et al., 1969). Five factors of job satisfaction were studied in the current study (coworkers, supervisor, work, salary and promotion). Cronbach's alpha for these items equals 0.78 . 


\subsection{Results}

Firstly, for determining the dimensionality of OCP in the study sample, exploratory factor analysis was used. O' Reilly et al. (1991) reported eight dimensions in their study, namely: innovation, outcome orientation, supportiveness, emphasis on rewards, team orientation, aggressiveness, attention to details and decisiveness. The results from factor analysis did not confirm multidimensionality as only one factor accounted for the $65 \%$ variance explained.

Descriptive analysis was used on all OCP and job satisfaction items. The analysis of the results demonstrated that fairness (mean $=2.21, \mathrm{SD}=1.08$ ), developing friends at work (mean $=2.24, \mathrm{SD}=1.16)$, respect for individual's right $($ mean $=2.18, \mathrm{SD}=1.19)$, being easy going (mean $=2.24, \mathrm{SD}=1.20)$ are the least stressed values in their organization. Contrary to that, employees considered high pay for high performance $($ mean $=3.59, \mathrm{SD}=1.09)$, result orientation (mean $=3.50, \mathrm{SD}=1.02)$, supportiveness (mean $=3.60, \mathrm{SD}=1.03)$, having high expectation for performance (mean $=3.62, \mathrm{SD}=1.01)$, and being competitive (mean $=3.45, \mathrm{SD}=1.1$ ) to be the most dominant values within the organisation. The mean score for job satisfaction equals $3.22(\mathrm{SD}=0.68)$.

Results of the correlation analysis including age, gender and organizational culture values are shown in Table 1. The results show that female respondents believe their organizations expects from them to respect individual right, to fit in, to be explicit and tolerant, whereas male employees feel aggressiveness and competitiveness is expected from them. When age, as a factor of job satisfaction was studied, the research showed that older employees felt that their organization gives high salaries, also that employees are not constrained by strict organisational rules and finally, that they receive due praise for high performance.

Interestingly, job satisfaction facets were found significantly correlated with 38 items of organizational culture. Items that were found highest and lowest in correlation are highlighted. Highest correlations were found for professional growth $(\mathrm{r}=0.65, \mathrm{p}<0.01)$, people orientation $(\mathrm{r}=0.55, \mathrm{p}<0.01)$, autonomy $(\mathrm{r}=0.54, \mathrm{p}<0.01)$, supportiveness $(\mathrm{r}=0.50, \mathrm{p}<0.01)$ and fairness $(\mathrm{r}=$ $0.50, p<0.01)$. Lowest correlations were found with working in collaborations with others $(\mathrm{r}=0.25, \mathrm{p}<0.05)$ and security of employment $(\mathrm{r}=0.22, \mathrm{p}<0.05)$. 
Management, Vol. 22, 2017, 1, pp. 35-48

P. Sharma: Organizational culture as a predictor of job satisfaction: The role of age and gender

Table 1. Pearson correlations for organizational culture items with gender and age

\begin{tabular}{|l|c|c|}
\hline \multicolumn{1}{|c|}{ Culture item } & Gender & Age \\
\hline Being explicit & $0.38^{* *}$ & \\
\hline $\begin{array}{l}\text { Respect for the individual's } \\
\text { right }\end{array}$ & $0.29^{*}$ & \\
\hline Tolerance & $0.45^{* *}$ & \\
\hline Being aggressive & $-0.26^{*}$ & \\
\hline Fitting in & $0.33^{*}$ & $0.29^{*}$ \\
\hline Being competitive & $0.26^{*}$ & $0.34^{* *}$ \\
\hline $\begin{array}{l}\text { High pay for high } \\
\text { performance }\end{array}$ & & $0.32^{*}$ \\
\hline $\begin{array}{l}\text { Offers praise for good } \\
\text { performance }\end{array}$ & & \\
\hline $\begin{array}{l}\text { Not being constrained by } \\
\text { many rules }\end{array}$ & & \\
\hline
\end{tabular}

Notes. ${ }^{*} \mathrm{p}<0.05 ; * * \mathrm{p}<0.01$

In order to test the stated hypotheses stepwise regression analyses was used. When all the employees were studied together, without taking into consideration age and gender, opportunities for future growth, enthusiasm for the job, fairness and good reputation were found to have a positive impact on job satisfaction. However, job satisfaction was negatively affected by aggressiveness (Table 2).

In the current study, separate regression was run to study the difference in organizational culture elements that affect job satisfaction of male and female individuals separately (Hardy, 1993). Results from Table 2 highlight that both male and female consider fairness and enthusiasm for work to enhance their job satisfaction. T-test was applied to assess the significant difference between male and female. Results from the t- test revealed that job satisfaction of male and female employees did not differ significantly on fairness $(t=0.60, p=n . s)$, whereas there was a significant difference in their job satisfaction in terms of paying attention to details $(\mathrm{t}=2.3, \mathrm{p}<0.05)$.

Interestingly, different organizational traits were found to influence male and female job satisfaction. Job satisfaction of male employees was found to be positively influenced by good reputation of the organization, freely sharing information and personal growth opportunities whereas stability and easy going atmosphere had a negative impact on their job satisfaction. Female employees' job satisfaction was found to be positively influenced by people - oriented culture, calmness, decisiveness and taking advantages of the opportunities. Their job satisfaction was negatively influenced by lack of rules. 
Management, Vol. 22, 2017, 1, pp. 35-48

P. Sharma: Organizational culture as a predictor of job satisfaction: The role of age and gender

Table 2. Regression analyses for job satisfaction

\begin{tabular}{|c|c|c|c|c|c|}
\hline & $\begin{array}{c}\text { All } \\
\text { employees }\end{array}$ & $\begin{array}{c}\text { Male } \\
\text { employees }\end{array}$ & $\begin{array}{c}\text { Female } \\
\text { employees }\end{array}$ & $\begin{array}{l}\text { Younger } \\
\text { employees }\end{array}$ & $\begin{array}{c}\text { Older } \\
\text { employees }\end{array}$ \\
\hline Fairness & $0.29 * *$ & $0.44 * *$ & $0.31 *$ & & $0.48^{* *}$ \\
\hline Being aggressive & $-0.20 * *$ & & & $-0.39 * *$ & \\
\hline $\begin{array}{l}\text { Opportunities } \\
\text { for professional } \\
\text { growth }\end{array}$ & $0.39 * *$ & $0.53 * *$ & & $0.31 * *$ & $0.60 * *$ \\
\hline $\begin{array}{l}\text { Enthusiasm for } \\
\text { the job }\end{array}$ & $0.31 * *$ & & $0.51 * *$ & $0.59 * *$ & \\
\hline $\begin{array}{l}\text { Having a good } \\
\text { reputation }\end{array}$ & $0.22 *$ & $0.21 *$ & & & \\
\hline Stability & & $0.22 *$ & & & $0.22 *$ \\
\hline $\begin{array}{l}\text { Paying attention } \\
\text { to details }\end{array}$ & & $-0.24 *$ & $0.26^{*}$ & & \\
\hline $\begin{array}{l}\text { Sharing } \\
\text { information } \\
\text { freely }\end{array}$ & & $-0.30 * *$ & & & \\
\hline Informality & & $-0.20 *$ & & & \\
\hline $\begin{array}{l}\text { Being quick in } \\
\text { taking advantage } \\
\text { of opportunities }\end{array}$ & & & $0.21 *$ & & \\
\hline $\begin{array}{l}\text { Emphasizing a } \\
\text { single culture } \\
\text { throughout the } \\
\text { organization }\end{array}$ & & & $0.33 * *$ & & \\
\hline $\begin{array}{l}\text { Being people } \\
\text { oriented }\end{array}$ & & & $0.38 * *$ & & \\
\hline Being calm & & & $0.30 * *$ & & \\
\hline Decisiveness & & & $0.23 *$ & & \\
\hline Being supportive & & & & & $-0.23 *$ \\
\hline $\begin{array}{l}\text { Working long } \\
\text { hours }\end{array}$ & & & & $0.17 *$ & \\
\hline $\begin{array}{l}\text { Not being } \\
\text { constrained by } \\
\text { rules }\end{array}$ & & & $-0.22 *$ & & \\
\hline Being different & & & $-0.26^{*}$ & $-0.32 *$ & \\
\hline $\begin{array}{l}\text { Being } \\
\text { competitive }\end{array}$ & & & & & -0.18 \\
\hline Adjusted R2 & 0.54 & 0.77 & 0.61 & 0.67 & 0.67 \\
\hline F- ratio & $29.15 * * *$ & $21.46 * * *$ & $12.32 * * *$ & $23.98 * * *$ & $25.69 * * *$ \\
\hline
\end{tabular}

Notes. ${ }^{*} \mathrm{p}<0.05 ; * * \mathrm{p}<0.01 ; * * * \mathrm{p}<0.001$

To determine the organizational traits which influence job satisfaction of older and younger employees separate regression analyses were performed. Mean age, which was 35, was used as a threshold. Results from Table 2 
Management, Vol. 22, 2017, 1, pp. 35-48

P. Sharma: Organizational culture as a predictor of job satisfaction: The role of age and gender

demonstrate that job satisfaction of both older and younger employees is influenced by opportunities for professional growth. Results from t- test highlighted that growth opportunities affected job satisfaction of older employees higher than their younger counterparts $(t=2.7, p<0.05)$. Furthermore, it was found that job satisfaction of younger employees was found to be positively influenced by enthusiasm towards the job and high pay for high performance whereas it was negatively affected by aggressiveness. Older employees were found more satisfied with their job as a result of fairness and stability, whereas competitiveness and informality impacted their job satisfaction negatively.

\section{CONCLUSION}

\subsection{Research implications}

Job satisfaction is said to positively influence individual's behaviour which facilitates organizations in developing competencies and gaining a competitive advantage (Scott-Cawiezell et al., 2005). The current study attempts to understand the organizational culture values that largely affect and influence job satisfaction of the employees. Since all values don't impact each individual equally, age and gender have been taken into account and the effect of the two on job satisfaction in light of organizational culture values have been studied.

The results from the study demonstrated that organizational culture values such as fairness, growth opportunities, job enthusiasm and good reputation of the organization affect the job satisfaction of the employees. The results of the current study are in line with the findings of Clark and Oswald (1996) who also found that fairness in the organization's processes and evaluations increase employees' satisfaction. Similarly, Kim (2002) and Arthur and Rousseau (1996) in their study revealed that opportunities for growth and development increase the job satisfaction of the employees. Reputation of the organization was also found to influence the job satisfaction of the employees which is in line with the findings of Lievens (2007) who also found respectable employer to be a factor in shaping individual's job satisfaction and willingness to stay in the organization. Promoting competitiveness among employees was found to affect negatively the job satisfaction of the employees. The reason behind such result could be the constant technological change that is happening in the IT sector which has made it already extremely competitive. Shellenbarger (2000) stated that organizations which foster aggressiveness are perceived as ruthless by the employees and are not considered conducive for long- term employment and satisfaction. 
When organizational values that influence the job satisfaction of male and female were studied, there were both similarities and differences in their opinions. Male and female both felt organizational fairness to be an equally important and equally strong antecedent to their job satisfaction. Attention to details is a factor, influencing the job satisfaction of female employees more than their male counterparts. Similar findings were found by Gilloran (1995) who also found female employees to be drawing more satisfaction from attention to details. However, William (1995) stated that male employees do not perceive attention to details as an appropriate leadership skill. Moreover, male employees felt growth and developmental opportunities, information sharing and employer brand to be a predictor of job satisfaction. Eagly (1987) also revealed in his study that men value ambition, dominance and clear rules and procedures in their job whereas female employees value single organizational culture and chance to take advantage of the opportunities (Terborg, 1977). This can be a possible reason for female employees preferring rules. Female employees consider people orientation a more important factor than their male counterparts. This is not only because of their nature (Eagly, 1987) but also because of the relational type of career women strive for (Powell and Mainiero, 1992).

The current study came up with interesting results when organizational culture values that affect job satisfaction were studied in respect of age. As expected, younger employees' satisfaction was influenced by job enthusiasm and opportunities for growth and development. A possible reason for this can be that, at present, there is cut-throat competition in IT companies and finding a promising job is a challenge. Thus, younger employees demonstrate high enthusiasm towards their job and are comfortable working long hours. On the other hand, older employees have already proved themselves to the organization and do not care much for competition and changes.

\subsection{Managerial implications}

The current study tried to map the organizational culture values that influence the job satisfaction of the employees. The results highlight all the values which an organization and a manager need to consider to enhance employee morale and employee satisfaction. The study also aimed at facilitating understanding of the difference in perception of organizational values on the basis of gender and age. As stated by Palthe and Kossek (2003), employees perceive organizational culture differently and their career progression is influenced by how well they feel they are able to fit within the organization (Young and Hurlic, 2007). 
Management, Vol. 22, 2017, 1, pp. 35-48

P. Sharma: Organizational culture as a predictor of job satisfaction: The role of age and gender

Results found fairness and growth opportunities to be significantly affecting job satisfaction of the employees. Thus, the IT companies should focus on introducing more transparency in their processes and policies. A company with clear policies and procedures is always preferred by the employees as the sense of justice dominates among them. An individual is more motivated and satisfied within the organization when they perceive themselves as growing personally and professionally. Growth opportunities in the form of promotion and increasing job responsibilities not only satisfy the employees but also affect their job performance, commitment and engagement positively. The companies with great career opportunities are always preferred among job seekers. Therefore, companies should develop clear career growth charts for their prospective employees. An average IT company employee spends around 10- 12 hours in the office and it is of vital importance that the employees feel enthusiastic towards the work they are doing. Interestingly, the enthusiasm for the job is of great importance to the young employees, thus the companies should provide all their employees, and young employees in particular, with the quality of work which will keep them enthusiastic. Individuals always prefer to be associated with reputed brands and employees are no exception. Employee's job satisfaction is significantly affected by the company reputation and bad news about the company not only affects its market position but hampers the employee motivation and job satisfaction. Thus, the companies, in case of negative publicity, need to maintain open internal communication with the employees and need to provide them with honest information since this prevents employees from trusting secondary information sources and develops their trust in the company.

\subsection{Possibilities for further research}

The present study was conducted only on three Information Technology (IT) companies, located in Pune. A similar study can be conducted for non-IT professionals. The current study did not consider the combined effect of age and gender. Therefore, the findings of the study can only be generalized after a more rigorous research on the impact of organizational culture values on employees' job satisfaction

\section{REFERENCES}

1. Aaltio, I., Mills, A. J. (2002). Gender, Identity and the Culture of Organization. London: Routledge.

2. Acker, J. (1998). The future of 'gender and organizations': Connections and boundaries. Gender, Work and Organization, 5 (4), pp. 195-206. 
3. Aiken, L., Havens, D., Sloane, D. (2000). The magnet nursing services recognition program: A comparison of two groups of magnet hospitals. American Journal of Nursing, 100 (3), pp. 26-36.

4. Ang, K. B., Goh, C. T., Koh, H. C. (1993). The impact of age on job satisfaction of accountants. Personnel Review, 22, pp. 31-39.

5. Bartol, K., Wortman, M. (1975). Male versus female leaders: Effect on perceived leader behavior and satisfaction in a hospital. Personnel Psychology, 28, pp. 533-47.

6. Bellou, V. (2007). Achieving long- term customer satisfaction through organizational culture: Evidence from health care sector. Managing Service Quality, 17 (5), pp. 510-22.

7. Brief, A. P., Rose, G. L., Aldag, R. J. (1977). Sex differences in preferences of job attributes revisited. Journal of Applied Psychology, 62 (5), pp. 645-6.

8. Buitendach, J. H., DeWitte, H. (2005). Job insecurity, extrinsic and intrinsic job satisfaction and affective organizational commitment of maintenance workers in a parastala. South African Journal of Business Management, 36 (2), pp. 27-37.

9. Clark, E. A., Oswald, A., Warr, P. (1996). Is job satisfaction U- shaped? Journal of Occupational and Organizational Psychology, 69, pp. 57-82.

10. Coh, C. T., Koh, H. C. (1991). Gender effects on job satisfaction of accountants in Singapore. Work amp; Stress, 4 (4), pp. 341-8.

11. Decker, P. J., Borgen, F. H. (1993). Dimensions of work appraisal: Stress, strain, coping, job satisfaction and negative affectivity. Journal of Counselling Psychology, 40 (4), pp. 470-8.

12. Detert, J. R., Schroeder, R. G.,Mauriel, J. J. (2000). A framework for linking culture and improvement initiatives in organizations. The Academy of Management Review, 25 (4), pp. 850-63.

13. Ely, R. J., Meyerson, D. E. (2000). Theories of gender in organizations: A new approach to organizational analysis and change. Research in Organizational Behavior, 22, pp. 103-51.

14. Helms, M., Stern, R. (2001). Exploring the factors that influence employee's perceptions of their organizational culture. Journal of Management in Medicine, 15 (6), pp. 415-29.

15. Huang, I. C., Wu, J. M. (2000). The corporate culture and its effects on organizational commitment and job satisfaction in public sector: An example of the Taiwan Tobacco and Liquor Monopoly Bureau. Review of Public- Owned Enterprises, 2 (1), pp. 25-46.

16. Igbaria, M., Guimaraes, T. (1993). Antecedents and consequences of job satisfaction among information center employees. Journal of Management Information Systems, 9, pp. 145-74. 
Management, Vol. 22, 2017, 1, pp. 35-48

P. Sharma: Organizational culture as a predictor of job satisfaction: The role of age and gender

17. Judge, T. A., Heller, D., Mount, M. K. (2002). Five- factor model of personality and job satisfaction: A meta analysis. Journal of Applied Psychology, 87, pp. 530-41.

18. McKinnon, L. J., Harrison, L. G., Chow, W. C., Wu, A. (2003). Organizational culture: Association with commitment, job satisfaction propensity to remain and information sharing in Taiwan. International Journal of Business Studies, 11 (1), pp. 25-44.

19. Moyes, G. D., Williams, P. A., Koch, B. (2006). The effects of age and gender upon the perceptions of accounting professionals concerning their job satisfaction and work- related attributes. Managerial Auditing Journal, 21 (5), pp. 36-56.

20. Odom, R. Y., Box, W. R., Dunn, M. G. (1990). Organizational cultures, commitment, satisfaction and cohesion. Public Productivity Management Review, 14, pp. 157-69.

21. Okpara, J. O., Squillance, M., Erondu, E. A. (2005). Gender differences and job satisfaction: A study of university teachers in the United States. Women in Management Review, 20 (3), pp. 177-90.

22. Okpara, J. O. (2006). The relationship of personnel characteristics and job satisfaction: A study of Nigerian managers in the oil industry. Journal of American Academy of Business, 10 (1), pp. 49-58.

23. Palthe, J., Kossek, E. (2003). Subcultures and employment modes: Translating HR strategy into practice. Journal of Organizational Change Management, 16 (3), pp. 287-308.

24. Platonova, E. A., Hernandez, R. S., Shewchuk, R. M., Leddy, K. M. (2006). Study of relationship between organizational culture and organizational outcomes using hierarchical linear modeling methodology. Quality Management in Health Care, 15 (3), pp. 200-9.

25. Pook, L., Fustos, J., Liviu, M. (2003). The impact of gender bias on job satisfaction. Human Systems Management, 22, pp. 37-50.

26. Sarker, S., Crossman, A., Chinmeteepituck, P. (2003). The relationships of age and length of service with job satisfaction: An examination of hotel employees in Tailand. Journal of Managerial Psychology, 18 (7/8), pp. 745-59.

27. Sarros, J. C., Gray, J., Densten, I. L., Cooper, B. (2005). The organizational culture profile revisited and revised: An Australian perspective. Australian Journal of Management, 30, pp. 159-73.

28. Savery, L. K. (1996). The congruence between the importance of job satisfaction and the perceived level of achievement. Journal of Management Development, 15, pp. 18-27.

29. Schein, E. H. (1985). Organizational Culture and Leadership. San Francisco, CA: Jossey Bass. 
Management, Vol. 22, 2017, 1, pp. 35-48

P. Sharma: Organizational culture as a predictor of job satisfaction: The role of age and gender

30. Silverthorne, C. (2004). The impact of organizational culture and personorganization fit on organizational commitment and job satisfaction in Taiwan. Leadership amp; Organization Development Journal, 25, pp. 592-9.

31. Smith, P. C., Kendall, L. M., Hulin, C. L. (1969). The Measurement of Satisfaction in work and Retirement: A strategy for the study of attitudes. Chicago, IL: Rand-McNally.

32. Uttal, B. (1983). The corporate culture values. Fortune, 108 (8), p. 66.

33. Verplanken, B. (2004). Value congruence and job satisfaction among nurses: A human relations perspective. International Journal of Nursing Studies, 41, pp. 74-92.

34. Wagner, W. G., Pfeffer, J., O'Reilly, C. A. (1984). Organizational demography and turnover in top management groups. Administrative Science Quarterly, 29, pp. 74-92.

Weisman, C. S., Alexander, C. S., Chase, G. A. (1981). Evaluating reasons for nursing turnover. Evaluation and Health Professions, 4, pp. 107-27.

\title{
ORGANIZACIJSKA KULTURA KAO PREDIKTOR ZADOVOLJSTVA POSLOM: ULOGA DOBI I SPOLA
}

\begin{abstract}
Sažetak
U ovom se radu analizira utjecaj organizacijske kulture na zadovoljstvo poslom, uzimajući u obzir spol i dob zaposlenika. Istraživanje je provedeno u tri poduzeća, koja se bave informacijskom tehnologijom, smještena u gradu Pune, u državi Maharashtra (Indija), s efektivnim uzorkom od 220 informatičkih profesionalaca. Prilikom prikupljanja odgovora koristili su se profil organizacijske kulture i deskriptivni opisi radnog mjesta. Podaci su analizirani uz pomoć deskriptivne statistike, višestruke regresije i t-testa. Rezultati pokazuju da vrijednosti organizacijske kulture, poput fer odnosa, prilika za osobni rast $\mathrm{i}$ organizacijske reputacije, imaju pozitivan efekt na zadovoljstvo poslom, dok organizacijska obilježja, poput agresivnosti, imaju negativan utjecaj. Daljnja je analiza pokazala da postoji i razlika u percepciji organizacijskih vrijednosti s obzirom na spol zaposlenika.
\end{abstract}

Ključne riječi: organizacijska kultura, zadovoljstvo poslom, dob, spol, Indija 